\title{
WestVirginiaUniversity
}

THE RESEARCH REPOSITORY @ WVU

Graduate Theses, Dissertations, and Problem Reports

1998

\section{Inside of Her}

Amy Lynn Fair

West Virginia University

Follow this and additional works at: https://researchrepository.wvu.edu/etd

\section{Recommended Citation}

Fair, Amy Lynn, "Inside of Her" (1998). Graduate Theses, Dissertations, and Problem Reports. 92.

https://researchrepository.wvu.edu/etd/92

This Thesis is protected by copyright and/or related rights. It has been brought to you by the The Research Repository @ WVU with permission from the rights-holder(s). You are free to use this Thesis in any way that is permitted by the copyright and related rights legislation that applies to your use. For other uses you must obtain permission from the rights-holder(s) directly, unless additional rights are indicated by a Creative Commons license in the record and/ or on the work itself. This Thesis has been accepted for inclusion in WVU Graduate Theses, Dissertations, and Problem Reports collection by an authorized administrator of The Research Repository @ WVU. For more information, please contact researchrepository@mail.wvu.edu. 


\title{
Inside of Her
}

\author{
By
}

Amy Lynn Fair

\author{
A THESIS \\ Submitted to \\ Eberly College of Arts and Sciences \\ at \\ West Virginia University
in partial fulfillment of the requirements
for the degree of
Master of Arts
in
English

Department of English

Morgantown, West Virginia

1998 
Copyright by

Amy Lynn Fair

1998 


\section{ABSTRACT}

\section{Inside of Her}

\section{By Amy Lynn Fair}

Inside of Her is a collection of linked short stories and poems that illuminate the life of a young woman named Ginnie Mudrich who constantly feels manipulated by her mother, Violet, and her childhood friend Anna. Ginnie realizes their control when she becomes friends with a waitress named Madeline. Through this friendship, Ginnie realizes that although she is in her early thirties, she is, in many ways, still a child. 


\section{Inside of Her}

By

Amy Lynn Fair

\section{A THESIS}

Submitted to

West Virginia University

in partial fulfillment of the requirements

for the degree of

Master of Arts

APPROVAL OF EXAMINING COMMITTEE

Kevin Oderman, Ph.D.

Gail Galloway Adams, M.A.

Date

James Harms, M.F.A., chair 
This is for Angela, for being Madeline

(and for the swim that started it all);

for my mother, Shine, for not being Violet;

for Rus Firman, because you deserve this much, at least;

and for Steven most of all, for his love and patience. 


\section{Acknowledgements}

I would like to thank Professor James Harms, my thesis director, as well as Professor Gail Galloway Adams and Dr. Kevin Oderman, members of my thesis committee, for their generosity, their patience, their criticism and their praise, as well as their valuable time throughout the creation of this thesis and the revisions that followed.

In addition, I would also like to extend an additional thank you to Professors James Harms and Gail Galloway Adams for their encouragement of the earliest pieces of this collection, as first seen in Creative Writing 301. They have given me the ability to believe in myself as a writer through their attentiveness and continual encouragement; I was made welcome in their classrooms, and in the creative writing program as a whole, and I always felt as if I was truly important.

A special, separate thank you to Dr. Kevin Oderman, for choosing to become a member of my thesis committee after reading only a small sample of my work, for adding a unique dimension to the revision process with his insightful comments (they often opposed everyone else's views and always offered me creative options that I hadn't even considered), and, most of all, for giving selflessly of his time. 


\section{Table of Contents}

Title Page $\quad$ i

Notice of Copyright

$\begin{array}{ll}\text { Abstract } & \text { iii }\end{array}$

Signature Page $\quad$ iv

Dedication $\quad$ V

Acknowledgments vi

Table of Contents vii

Introduction $\quad 1$

Learning to Settle Down $\quad 5$

14th Avenue at Olive $\quad 13$

The Night She Saw a Strange Man Naked 14

$\begin{array}{ll}\text { Wading } & 15\end{array}$

Inside of Her 16

Progress, As She Sees It in the Late Twentieth Century 19

$\begin{array}{ll}\text { Soap and Water } & 20\end{array}$

She Cannot Control the Aging Process 23

She Had a Shine about Her $\quad 24$

The Night You Shouldn't Have Taken Her Home 28

$\begin{array}{lr}\text { Omelet Boy } & 29\end{array}$ 
She Met a Woman Who Was a Doppelganger from Afar 31

$\begin{array}{ll}\text { A Childhood Fear } & 35\end{array}$

Love Is Not a Fritatta $\quad 36$

The Foolish Confidence of Girls Who Do Not Wear Bras 46

In a Manner of Speaking $\quad 47$

She Frequented a Gas Station $\quad 51$

Dinner For Two: Discussing a Third Party, Alluding to a Fourth 53

The Day I Met the Barista Who Took My Place 60 


\section{Introduction}

or, "Behind Her"

Inside of Her is the story of Ginnie Mudrich, a twenty-nine year old woman who considers herself an aggressive, educated woman, content in her independence, who has successfully fought to keep her overbearing mother, Violet, from interfering in her personal life. However, through forging an unlikely friendship with a waitress named Madeline, Ginnie realizes that while pushing her mother away, she has allowed her best friend Anna to take over making her personal decisions for her. Madeline's presence offers confusion as well as insight, as the companionship causes Ginnie to recall failed relationships of her past as well as evaluate and determine the salvagability of her present ones.

Let me be the first to admit that, in many ways, it sounds as if this story has been told before. A woman is happy until a new person in her life stirs thing up ... and the woman is then unhappy until she makes major changes in her life. I don't believe, however, that is where this story ends. Though at times I travel close to familiar roads, I don't believe that it's necessary to avoid them altogether in the search for something new. Ginnie's story is one that attempts to illustrate the diaphanous layers of the friendship between two strong women: not borne of gossip over tea, not overtly sexual, not black or white. Instead: intelligent, nurturing, variations of gray. 
I decided early on that I wanted Inside of Her to be a collection that mixed both poetry and fiction, but I had no idea about how to begin organizing or even telling a story in such a way. As it happened, I spent a great deal of time fleshing out the prose stories about Ginnie and Madeline, knowing what I wanted to happen and what I wanted to leave out, understanding what needed to be covered. The poetry, on the other hand, came from something (or somewhere) entirely different.

In the course of trying to experiment with changing the style of my poems, trying to tie them to the growing collection of short stories, I first tried "giving" some of the poems to Ginnie, so that they were more specifically persona poems, but I never seemed to be able to make it sound anything but trite or gimmicky. From those attempts, though, came the revisions that brought this work together in its present form. In trying to change the poems into something Ginnie had written, I changed all first-person pronouns to third-person "she"s and "her"s. From there, I found I was liberated; I was no longer writing about me, or trying to give my poems to Ginnie, but I was writing more specifically about her. When I felt that I needed to show small, condensed portions of Ginnie's persona, I turned to that same poetry, and something between the poetry and fiction just clicked. The poetry tends to show Ginnie's vulnerabilities more and deals directly with Ginnie's observations of the people around her and the circumstances that she feels are slowly consuming her.

The short fiction, in contrast, offers observation of Ginnie and her interactions with others, though with a deliberate distancing of the narrator. I have kept dialogue to a minimum on purpose in many of the pieces to maintain that distance. I had to work hard to try to add dialogue for some of the supporting characters; in revision, it became obvious that it was necessary to give readers a chance to hear their voices as well as Ginnie's voice. The last pieces to be written, the succinct, matter-of-fact prose pieces like "She Frequented a Gas Station" and "A Childhood Fear," contain no dialogue at all, and I think of them as a blending of the techniques used in creating 
the poetry and fiction. I feel that they allow the reader deeper into Ginnie's emotions than the rest of the prose, but still maintain a substantial distance from the action taking place (in a way that the poetry does not).

I am not sure what the future holds for Inside of Her. I hope to experiment with removing the poetry from the collection and attempting to rewrite the interweaving stories, adding more of them to create a sort of patchwork novel, similar to Alice Munro's The Beggar Maid. I do know that if I decide to leave Inside of Her as it is now, I will have to fight the urge to continue Ginnie's story every time I sit down at the computer. Now that I have created her, she has a whole life to live. I am relatively new to writing fiction, and I find that fascinating; whether I really need to record any more of Ginnie's life is another matter entirely.

In giving credit to the conception of this collection, I initially wanted to list page after page of writers who I consider to have been influential. I don't really like thinking that any one of them is more present in my work than another, but I will try to limit myself to mentioning those writers and their works that I feel the shadows of whom are clearly present in Ginnie's story. Lydia Davis' book Break It Down greatly influenced me throughout the process of revision as well as specifically in the writing of "In a Manner of Speaking." Davis uses few or no proper names in her short stories, and this was something that I tried to do in a few pieces because I was intrigued by how far removed Davis' overuse of pronouns made me feel from the characters in her stories. For a similar reason I looked to Jeanette Winterson's Written on the Body. The ambiguity of the narrator's gender affects the reader's interpretations of the novel's central relationship, and that was something that I thought about while trying to create a relationship between Madeline and Ginnie that was not easily pigeonholed.

In addition, Lydia Davis' novel The End of the Story, about the emotional aftermath of a break up, challenged what I thought to be the limits in attempting to 
illustrate a character's struggle with self-confidence and self-worth. I would feel guilty if I did not mention it, too.

In addition, I owe a great deal to Amy Bloom's collection Come to Me, especially "Love Is Not a Pie," from which I formed the title "Love Is Not a Fritatta," which now functions as the title of a short story, but at one time was the title of the entire collection. Bloom's "Love Is Not a Pie" is one of my favorite stories, one to which I continually compare almost every short story I read. Also deserving mention is Kim Addonizio's Jimmy and Rita, the first book I ever read that combined poetry and fiction in the telling of a central story. Although I know that my work differs greatly, I also know that Inside of Her would not be a mixed-genre work without my having read Jimmy and Rita.

I will also mention, in no particular order, for their overall influence, and for the risks they take, including their ability to illustrate the absurdity and quirkiness of life, and not always doing so in search of humor: Mary Gaitskill's Bad Behavior, The Wrecking Yard by Pinckney Benedict, Jane Hamilton's The Book of Ruth, Lorrie Moore's Anagrams, Suspicious River by Laura Kasischke, Jill McCorkle's Crash Diet, and Tama Janowitz's Slaves of New York. Limiting this to works that directly influenced this body of work was difficult; I wanted to name many, many more.

Now that this collection is finally collected, I can appreciate being able to stand back from the physical and emotional bulk of it. Wringing it out of myself and out of other women that I have known now seems so easy. I constantly have to remind myself that it was not easy at all. This will, no doubt, function as a reason to never stop writing--so that I don't forget how hard it is. 


\section{Learning to Settle Down}

Every Sunday, over turkey club sandwiches, ginger ales, and a shared slice of cheesecake, Ginnie and Anna talked about babies. Ginnie often mentioned she was sure that all babies had a smooth, sticky, hard surface, like mouth-moistened hardtack candy, and it always, without fail, pissed Anna off. For as long as Ginnie could remember, Anna wanted a baby. The topic was unbearable for Ginnie, who disliked children without shame, but Anna chattered on all the time about having them. Anna had just become engaged and was anxious to begin a family. For Ginnie, both of those facts meant that fresh, original lunch conversations with her best friend had become a thing of the past.

"All I want, besides a baby, is for you to just find someone, someone wonderful like Mickey, and settle down. I want you to start a family, too." Ginnie grew tired of hearing about it. Anna had always been stubborn and self-absorbed; Ginnie had actually liked that about Anna when they were younger, but things slowly changed. Anna had become more spoiled and inflexible; she disregarded Ginnie's opinions about her own life. Ginnie told Anna, reminded her, that she liked living alone, but Anna acted as if Ginnie did not know what was best for herself. Ginnie resented Anna's interference, but she tried to be vocal about it without putting a strain on their friendship. Ginnie had trouble admitting that it was Anna who was the source of any strain, because she knew that Anna didn't mean anything by her actions. Anna continued to try to arrange dates for Ginnie. Ginnie was usually ready to throttle Anna by 2:00 on Sunday, so their lunch dates were often cut short 
by Ginnie, feigning a headache, leaving the restaurant early with her half-eaten lunch encapsulated in a Styrofoam box, trying to avoid a scene.

Anna and her boyfriend Mickey met while Ginnie was attending college in San Francisco. Mickey worked at the Eugene Plasma Center when Anna was hired to file charts and take pulses in the reception area. Mickey worked as a phlebotomist on the donor floor. Ginnie stayed in san Francisco for a few years after graduating; in hindsight, she wished she would have never left Oregon in the first place.

Ginnie Mudrich and Anna Barringer almost grew up together. They went to the same grade school and junior high, but they traveled in different circles and became close when they were both sixteen. It was as if they endured all of those years of public schools because they somehow knew they would eventually find each other in the halls, in front of a dented locker or eating lunch from a brown paper sack, not in the crowded cafeteria, but on a bench outside, away from everyone.

Ginnie remembered how guilty she'd felt when she left Anna behind to move to California to go to school; she'd felt even worse when she returned after her senior year to meet Mickey. It was meeting him and seeing Anna with him that had made Ginnie decide to stay in California another two years. She knew she could have steered Anna away from him and their train wreck of a relationship if she'd lived in town when Mickey first asked Anna out. She not only felt as if she had lost her best friend, she'd gained yet one more annoying, stupid man in her life, if only indirectly.

The plasma center had eventually closed; Mickey had been transferred to another office in the neighboring town of Springfield. Anna'd been laid off. She had taken the opportunity to go to a technical school, but even with a medical certificate, she still remained unemployed. Ginnie assumed that it was all that time alone at home that made Anna decide to work on getting pregnant. It was just like Anna to think that she might as well have a baby if she was stuck at home all day anyway. 
Ginnie wondered if Anna realized that once she had a baby she wouldn't be able to sit around the house anymore. Anna probably hadn't given that a second thought.

*⿻丷木

Ginnie lit a Newport while grinding the last of a one-pound bag of Kona coffee and waiting for a wheat bagel to toast under the broiler. She absently crimped the wrong end of her cigarette between her front teeth and lit the filter with a kitchen match.

"Shit," Ginnie hissed as she threw the melting cigarette into a sink full of cooled dishwater and slid another from the pack on top of the fridge. It was Sunday morning, and Anna hadn't called Saturday night to confirm their brunch date. It was unlike her, and Ginnie figured that Cawley had something to do with it.

Cawley was Mickey's best friend. Almost a year ago, shortly after Ginnie moved back into town, Anna and Mickey had introduced Ginnie to Cawley, hoping the two of them would find they had something in common. Anna'd invited both of them to dinner one night, expecting magic to happen. Although Ginnie was initially interested in Cawley and had accepted the first few of his invitations out, she quickly grew tired of him insinuating himself into her life. He'd tried to become a permanent fixture in her life too quickly, and after he'd spent six nights in a row at her apartment without being invited, Ginnie stopped returning his phone calls. She'd never thought she had to break up with him, but the situation became ugly. He'd mistakenly thought he was her boyfriend. Cawley called several times a day, getting out a frantic, "Ginnie, please don't hang up on me!" before Ginnie hung up on him. He also began calling just to see if she was home, hanging up if she answered. It wasn't really his fault, Ginnie knew, because Anna and Mickey encouraged him to think that she would have a change of heart. 
Anna's favorite thing to say to Ginnie about the relationship was, "Cawley went out of his mind when you said you wouldn't date him any more!" She never went into specific details as to exactly how he went out of his mind. Anna and Mickey both tried to cajole Ginnie into seeing Cawley again. Cawley begged them to interfere on his behalf, Anna said, but Ginnie did not waver. Ginnie maintained that she would have nothing to do with him. If he began to have an influence on with her brunch dates with Anna, Ginnie knew she would kill him. Despite the monotonous conversation, Anna was her best friend, and those brunches were the only time they spent together between the demands of Ginnie's job and Anna's Mickey.

Ginnie was worried, but she told herself to wait until ten before calling Anna. Ginnie wasn't really in the mood for any of the entrees at the Solstice. She hated the restaurant. Anna knew that, but she loved dragging Ginnie there anyway; Ginnie was prepared to offer to meet Anna there, as a sort of bargaining chip. Ginnie knew the value of sacrifice when it came to friendship. She ate the mediocre food on the Solstice's menu without complaint, though it only made her think of the places they used to go: a Portuguese place, a diner that served great omelets and burritos, a Thai restaurant, and sometimes a pancake house. They used to rotate a handful of restaurants, and they'd been going to them for so long that the Sunday waitresses at each of them knew their names. That was in the past, though. Ginnie braced herself for some variation on the dry, broiled chicken breast and limp, over-steamed green vegetable she always ordered.

米

Ginnie and Anna became friends during their junior year of high school when the school buses were re-routed mid-year and they both ended up on bus 19 in the mornings. Both girls were awkward and shy, but within the first two weeks, they were sitting together, quietly laughing and making fun of their schoolmates. It was a 
friendship of abounding sarcasm and superiority more than shyness, and even then Ginnie thought she'd be friends with Anna forever. They shared everything. Anna taught Ginnie how to shoplift cosmetics; on the weekends they went the stores where Anna said they wouldn't get caught. Between the two of them, they owned every color of lipstick offered by L'Oreal and Revlon in 1984. Ginnie's favorite at the time was Bronze Coin, a pale, shimmering beige. Worn over a liberal coat of black Halloween lipstick, Bronze Coin turned into a lurid, sickly color like that of old, graying meat. Ginnie had a tube of Bronze Coin in every purse and satchel she owned.

Anna was the only person Ginnie ever brought home after school. Violet, Ginnie's mother, was loud and overbearing, and the house usually looked as if it had been ransacked. Often, it had been; Violet tore the place apart looking for something she had lost, usually accusing Ginnie or her younger brother Stuart of misplacing or hiding it. Ginnie never understood how her mother was a hippie in the sixties; Violet seemed too high strung for all of that.

Ginnie's father, Lou, once told her, "Your mother changed when she became pregnant with Stuart. She used to be so relaxed. It was like she could tell, even while he was still inside of her, that he was going to be a hellion."

Ginnie agreed that Stu was a hellion, but was surprised her mother's condition wasn't pinned on her; most family problems were. Ginnie told Anna that her parents met when her mom went in to a student-run drug counseling center. She was counseled by Lou, and they married a few months later, moving to Oregon to start a family. Ginnie and Anna laughed, wondering out loud what Violet must have been like when she was stoned. Anna never acted uncomfortable at Ginnie's house, even when Violet was rude or clinging or accusatory. She imitated Violet's drawling "company" voice with great skill, "Don't caaall me Mrs. Mudrich, caaall me Viiiolet, sweetie." 
Violet spent more time taking care of her family than herself, so every day was frayed at the edges a little when she neglected her own diet or forgot to take her vitamins because she was too busy mothering everyone else. Ginnie's older sister, Laurie, moved out right after her eighteenth birthday. Laurie said she couldn't take Violet any more, but it was Ginnie's opinion that once Laurie started a family, she treated her own children the same exact way Violet treated Laurie, Ginnie, and Stu.

In high school, Anna laughed at Ginnie for keeping an inhaler with her at all times, for feeding one of Violet's nuttier behaviors. Ginnie sprayed it into the air a few times a day; if she didn't empty it regularly, Violet knew she wasn't using it. Ginnie tried to play along so as not to cause any problems, but she knew she didn't have asthma.

Ginnie's father was quiet most of the time; he tried to live his own separate life in the same house as Violet. After Ginnie's parents moved to Medford, Anna accompanied Ginnie on visits. Anna had often experienced how needy Violet was, so why did Anna want Ginnie to remain in a relationship with someone as needy as Cawley? Anna should have realized that Cawley was the last kind of man that Ginnie needed in her life, and Ginnie was running out of ways of trying to explain that to her.

米

Ginnie wove a path to her bedroom through the stacks of books and unread manuscripts that littered her apartment's floor, absently carrying her empty coffee cup. She picked out her clothes for the day, khaki capri pants and a rose-colored angora shell but decided to call Anna before getting dressed.

"Hello?" Anna answered on the first ring. Ginnie was sure by Anna's tone that she knew it was Ginnie on the phone, that she had been waiting for Ginnie to call. 
"Anna, it's Ginnie. I was going to call you last night about brunch today, but I went to bed early with a headache." Ginnie made up the part about the headache. "I thought I'd call this morning just to make sure we're still meeting, as usual."

"Oh," Anna responded, surprised, not angry. Ginnie was sure that she had just spared herself a future discussion about "taking Anna for granted."

"How about meeting at one at the Solstice?" Ginnie asked.

"That's good." Anna didn't even suspect that Ginnie was consciously trying to be nice. Ginnie hated that about Anna; she complained if Ginnie was inconsiderate, but never noticed the occasions when Ginnie was thoughtful.

"I might be a few minutes late, as usual; the after-church traffic is unpredictable, but it's a bitch on a bike to get around downtown. There's no way to predict how long the ride will take me. You know, all those scary old people in big cars, not realizing bikes have the right-of-way at intersections," Ginnie said.

"Wait a minute, did you say you were a bitch on a bike?" asked Anna, laughing. Ginnie, unamused, didn't answer. "I can pick you up, you know," Anna offered as an apology, though Ginnie always declined.

Ginnie lightened. 'I'll get there, don't worry. You know I don't need a ride. If I'm running late, just reserve the biggest chunk of whatever's chocolatey on the dessert cart today before the old ladies from St. Aloysius buy it all up. I hate it when we have to eat that shitty apple pie."

"What a sweetheart you are; but, at least, a sweetheart with priorities. I'll see you." Anna laughed, said good-bye, hung up.

Ginnie felt several degrees better about everything, and Cawley hadn't been mentioned once in the conversation. However, Ginnie thought, the conversation had been short. For once Ginnie hoped she would be able to steer their conversation toward babies and away from her love life. Deciding to treat herself to a matinee after brunch, Ginnie pulled on her clothes, walked back through the apartment, and 
opened the front door to retrieve the Sunday edition from the porch. She also grabbed Saturday's mail, which she dropped on the coffee table, adding to Friday's heap of bills and catalogs. Back to the kitchen table, she cradled the headlines against her chest and fished the movie listings out of the Lifestyles section, hoping the Bijou was showing something without subtitles, something easy to digest. 


\section{$14^{\text {th }}$ Avenue at Olive}

That morning, her lungs hitched, stiffened by cold air mingled with the still-landing frost. She smelled April's first lilacs, faintly, through ice. Frosted like small grape candies, clustered blossoms hung, suspended temporarily in their opening.

Wiry bushes, their branches ice burdened, lined the driveways and side yards she passed; they bowed over the uneven sidewalks, buckled by too many early thaws, late frosts. She rode her bike at dawn, eyes watering; the movement itself made her even colder.

At home, she had arranged lilac cuttings the day before, now fortunate in their lazy, rootless rim-dangling. In a pickle jar filled with sweet-water, they were made fresh by the lingering steam of her shower.

She felt, as she pedaled, as if she could not control the slowing down of everything around her. The winter was becoming longer, and no one noticed. It curled around the edges of both Summer and Spring, having already engulfed Autumn in its entirety.

April and August, especially. It singled her out, meaner to her than to other people. Creeping under her woolen sweater and scarf as she rode home, under flannel pajamas as she stood on her small porch, drinking coffee; it stung her skin, puckering it to goose-flesh. As if she was sleeping, winter continued to fall over her like a smooth, crisp sheet tangled around her legs. She could not kick it free. 


\section{The Night She Saw a Strange Man Naked}

They were sitting by the Willamette River that night, barefoot, a bright moon above, drinking wine from a bottle, watching the clusters of night fishermen on the opposite bank. Anna pointed out that the limited, circular glow of each campfire enclosed a little scene like the dioramas they used to make in grade school by putting twigs and rocks into upturned shoe boxes. Occasionally, they'd hear splashing water and laughter as people waded in the dark; maybe skinny dipping, they snickered. Or bathing.

Just then, someone emerged from the water directly in front of them. Ginnie held her breath; Anna clutched her arm at the elbow with both hands. He must have made his way over from the other side of the river. It was possible; at that point in the river, it was shallow enough to stand on the bottom almost all the way across. The water moved swiftly, though, and the girls were surprised that someone would try crossing it in the dark. He pulled himself out of the water and stepped across the stones at the edge, shaking long, unkempt hair out of his eyes. He was naked. In the moonlight Ginnie and Anna could see his shriveled penis, no more than a knuckle under an unruly patch of wet, dark hair and a rounded, luminescent belly. The two girls sat silently, crouched in the brush, as he called, "Sher-rree? Sherr-eee!" down the bank in both directions. About a hundred feet down to the left, someone blinked a flashlight in silent response, and the man trudged off in that direction, the flesh of his backside pale blue in the wash of moonlight. 


\section{Wading}

I don't remember the humidity, but the sun that summer burned through the cool air at the water's edge, turning my bare shoulders to blisters as we waded in the creek-shallow Willamette River in our underpants, too itching with heat to have any shame.

Fishermen fired their tufted flies into the icy-cold current right upstream; we stretched out naked in the sparse grass, baking our winter-weary hides to crimson from creamy, pale pink before biking into town again, drying our bras and panties in the sun by folding them over the fallen branches that hid our section of the shore. 


\section{Inside of Her}

Ginnie never really considered herself to be all that difficult to get along with, but she was often alone. She had been involved in unsuccessful relationships with two women during college and refused to go out with men because she found most dates harrowing. She was in love with a woman once and had once dated another, different woman, but both relationships made her certain that she would be just as uncomfortable with herself if she was a lesbian.

Years before, she had fallen in love with Ruth, her college roommate, but never tried to pursue a relationship because they were friends. Ginnie didn't have many friends, and she'd always resisted the frequent temptation of kissing Ruth; she'd thought about it most often when Ruth would return in the morning from track practice. Ginnie had felt that she couldn't afford to lose one of the few friends she did have, should Ruth reject her. She was also not sure what she would do if the opposite proved true, that Ruth shared the attraction.

Ginnie had briefly tried to date another girl, Nan, if hanging out at Ginnie's apartment and drinking wine was a date. At that time, Ginnie was older but still in college, living in an off-campus apartment. She'd decided to try very hard to think of herself as gay. She idealized what it would be like to have a female lover. She wondered if the troubles she had with men would disappear with women, because she thought that women, by nature, were considerate, understanding, and nurturing. Nan was none of these things. Ginnie thought that Nan would move in with her and 
they would start a serious relationship. Ginnie soon found out that Nan had a healthy sexual appetite and liked to sleep around; she often used women, just like many men that Ginnie had dated in the past. So she told Nan that she would not sleep with her unless she quit having sex with other women. Nan got tired of waiting on Ginnie, and she refused to be monogamous. Nan soon moved on; Ginnie was left alone.

She decided not to be gay.

She thought about Ruth a lot after that; even after Ginnie received her degree and Ruth moved out of the apartment, the two wrote to each other at holidays and sent postcards to one another from their respective summer vacation spots. Ginnie still refused to tell Ruth that she loved her, because she was so good at loving Ruth behind her back. The last time that Ginnie had seen Ruth was during their final term of school; Ginnie drove her to a drug store to buy aspirin and Band-Aids. Ruth was moving in with a new boyfriend, Jack, who suffered from a seemingly never-healing canker sore in the corner of his mouth that repulsed Ginnie. He soon became Ruth's husband. Ginnie never said so, but she knew that Ruth could sense her disapproval. They fell out of close contact soon after that.

She often pictured Ruth in the passenger seat of her car, rifling through her plastic bag of drug store purchases. Along with Band-Aids and aspirin, she had bought a pair of Halloween socks, a large bag of Swedish fish and a card of bobby pins. Ginnie knew this because Ruth had inadvertently dropped her receipt on the floor of the car; Ginnie saved it, pressing it between the pages of an old art book. Ruth's cheeks had been full of the sweet, gummy pulp of the chewed-up candy, and Ginnie smiled at her as she drove her home, thinking, this is how I will always remember her. It was how she always remembered her, even when she tried to remember different days that they had spent together. She was able to picture Ruth in other places if she concentrated, like the museum café where they occasionally met 
for lunch to complain about the bland food, or seated at a desk in one of the painting classes they had shared, or in a vinyl booth at one of the bars they frequented on weekends (they all had vinyl booths), but in these memories, Ruth always had a slimy mouthful of candy, her teeth slightly pink from food dye.

Ginnie didn't date other people, claiming to friends that tried to fix her up that she was not interested, that she did not want to date. She spent a lot of time alone and used that time to rationalize the poor choices she had made in her life. She told herself that she didn't really love Ruth because she had no desire to sleep with her. She had never shown Ruth how much she loved her by using her fingers or her tongue. When Ginnie was with Ruth, she never had to be inside of her. 


\section{Progress, As She Sees it in the Late Twentieth Century}

During the week, his sideburns sometimes seem to grow longer and sharper across his cheeks. On certain Wednesday nights she believes them to be at maximum potential. Often she is proved wrong.

The two pass each other by the downtown furrier but occasionally closer to the front of the library. Sometimes he smiles absently, and in his being polite the sideburns raise slightly, with his ears.

She tries to categorize them when she sees them; they do not exactly meet the criteria of mutton chops. She tries to pinpoint their ancestry with casual glances as she walks past them on her way home.

It seems they constantly reach for, but fall short of, the corners of his thin mouth.

He must rein them in, she thinks, clip their curled wings on Thursday or Friday nights, before dates.

Only she sees them at their most defiant, on Wednesdays. He surely renders them less ghoulish for weekends, not wanting to ruin his chance with a girl in tight, flared Levi's worn with a thin halter or blouse and black platform boots. 


\section{Soap and Water}

Victor drew enough attention to himself without the dirt and stench he so carefully cultivated; he was barely five-foot-five and weighed so much he'd make almost anyone wonder where he found pants so short and so wide. He had a hefty fellowship at San Francisco State---he was supposedly some kind of genius---but he lived in a run-down boarding house and no one knew where he spent all the rest of that money. Ginnie and Ruth knew only that it wasn't spent on shower gel or coinoperated washing machines. Ruth used to try to make Ginnie retch during dinner by saying it went to hookers.

Ginnie hadn't spoken to Victor in years---they'd had an argument a few months before Ruth moved out of the apartment she shared with Ginnie. He was there, visiting Ruth while Ginnie was still at work---that was when Ginnie was still a grill cook down at the Dairy Queen, so she was more often surly than gracious by the time to clock out rolled around. That evening, when Ginnie walked up the steps and opened the front door, the smell hit her before she even saw him. As she turned to make her way into the living room, she found Victor sitting on the couch---not even making conversation, just reeking. Ginnie tried to be calm, but at the time, that couch was their only piece of legitimate furniture---everything besides that couch and the mattress and box spring set was scavenged from nearby alleys on the nights before trash pick-up. 
Ruth was just returning to the living room from the kitchen, holding two tumblers of iced tea. The surprised, slightly fearful, look on Ruth's face told Ginnie that her aggravation was apparent. No one spoke, but Victor's mouth curled into a faint smile as he reclined on a decorative grouping of second-hand toss pillows. After about thirty seconds of silence, all ability to remain rational drained from Ginnie, and she felt agitation creeping like a wet stain, settling in the apples of her cheeks. She opened her mouth; at first just for a few large gulps of air, but words clamored for an escape, following on the heels of her first exhalation.

"What the hell is wrong with you? Can't you be satisfied to stink up our floor when you visit? Now we'll never get the foul smell of your sweaty ass out of that upholstery! It's brocade, you stupid ... fuck!"

Victor just sat there, as if he had fully expected the outburst, as if Ginnie had merely called, "Honey, I'm home," as if he took great pride in his own stench. She stomped past him and into the bathroom, slamming the door behind her, trying at the same time to make herself believe that she had indeed just yelled at Victor, a guest in her home, for sitting on her couch. As she calmed down, she began to snicker quietly, behind the palms of her hands; she worried about Ruth's reaction. It was their home. Their couch. Ruth had paid for half of the couch, after all, Ginnie thought, and maybe Ruth didn't care that Victor reeks. Ruth could take Victor's side; Ginnie thought that when he came to visit from then on, he would have permission to sit on only one particular half of the couch. It could become a bone of contention between her and Ruth---they could end up hating each other.

Finally, not being able to stand it, Ginnie wanted to find out if Ruth really was pissed at her. As she slowly opened the bathroom door, she realized that the living room was empty---Victor was gone. She hadn't heard him move from his perch while she was in the bathroom; she would have thought she had imagined the 
whole incident, but in his absence, a faint smell of his unwashed skin lingered in the air. Ruth appeared in the kitchen doorway; she was armed with a can of Lysol, and with it she began hosing down the living room. She looked at Ginnie sourly, and Ginnie closed her eyes in dread. When nothing happened after a few seconds, Ginnie opened them. She saw Ruth's dour, pursed lips begin to give, and she started laughing. Doing her part, Ginnie dug in her purse for a lighter, and she lit the few scented candles they owned, placing them in front of open windows.

After that, Victor never came to visit them again. Ginnie occasionally saw him as he sat, oblivious to her observation, engulfing a four-egg black-bean-and-salsa omelet at a little café a few blocks up from their building. Ginnie swore that every single time she passed, she could smell him right through the windows; sometimes she held her breath as she hurried home, hoping he wouldn't see her. 


\section{She Cannot Control the Aging Process}

Carmine is her least favorite color but not for the most obvious reasons

(for its unapologetic, orangey harshness

that clashes with most skin tones),

but because she fears what it stands for.

It has become her spinning wheel.

She knows that some day, In spite of warnings by others, she won't be able to stop herself from wearing it.

It will fill the gold-plated Coty tube of waxy lipstick in her best Sunday clutch, and she will drop it into sateen darkness after every use to mingle with old receipts and torn, half-sticks of DoubleMint and clink against bobby pins, loose change, and a tin of aspirin.

It will be cushioned by crumpled Kleenex and a plastic rain bonnet folded carefully into its own snap pouch. She calls herself Aurora, knowing she will not be able to stop Carmine from making her old. 


\section{She Had a Shine About Her}

Sometimes, while preparing for a visit to her mother's, Ginnie packed her bags (an old canvas duffel from the Gap and a paper shopping bag), and wished that she still found twenties in her jacket on the ride back to her own apartment. She thought that the money, slipped into her pockets by her father, would somehow make the trips a little more worthwhile. As it stood, she felt as if she got nothing out of visiting her family.

She knew her father thought she was now too old for a twenty dollar bill to amount to much, but he was wrong. Credit card balances, rent, groceries, Sunday brunches downtown, and a never-fully-paid dry cleaning tab kept any part of her paycheck from ever drifting to the bottom of her savings account. Ginnie realized that she could give up purchasing tinned artichoke hearts and imported lemon curd, or start hand washing her sweaters in the bathroom sink, but what, she thought, would she do with the extra money? See a movie, maybe, and then spend the next three days angry at herself because she should have known that the screen adaptation could never be as good as the book. That, in turn, would anger her, making her feel like a cliché, a literary snob living hand to mouth, wearing two pairs of socks to bed and leaving the heat turned off at nights, eating her seven-dollar-a-jar fruit spread on store-brand English muffins in the mornings. Then she would just become angry at herself, her whole existence, and wouldn't do anything but lounge in bed reading 
People magazine and The New Yorker, eating fatty things. Tantrum food, her mother always called it, clicking her tongue at one more in a long list of Ginnie's weaknesses.

Ginnie liked chocolate, but when she was in one of her moods, she preferred salty things, especially those boxed snack crackers that are supposed to taste like bacon or chicken. She always kept a box around, but usually in her bedroom closet, for two reasons: when she really needed them, she usually didn't have the energy to walk to the kitchen to get them, and so that nosy friends would not find them if they were to open a kitchen cupboard. She felt that she had to keep up a certain image, and chicken-flavored crackers were in no way part of it.

Ginnie's closest friend Anna was in worse financial shape than Ginnie, but Ginnie constantly lectured Anna about her habit of cutting corners in the wrong places. Anna would invite Ginnie over for boxed pie or doughnuts, which Ginnie was more than willing to eat; however, Ginnie's ears pricked up, even from a room away, when Anna pulled the plastic vacuum lid from her can of Folger's. Ginnie never missed an opportunity to refer to it as Utility Roast with a snarky chuckle.

Anna felt she had to buy her coffee in big aluminum tubs to save money, but Ginnie always chastised her, often saying, "Anna, there is no amount of money worth saving if it means you have to live your life drinking shitty coffee." Ginnie only bought hers whole bean, in colorfully-printed waxed paper bags. "I have priorities, Anna," she said, "even when I'm broke." Anna never answered, maybe embarrassed, maybe not wanting to start an argument with Ginnie over ground coffee.

Ginnie traveled to her mother's house infrequently, making promises that were eventually broken, constantly paring down the frequency of her visits. When Ginnie's father had retired a few years before, her parents had moved away from Eugene to a little house just north of Coos Bay; Ginnie joked that they did it to use the nearby beach to entice their children into staying for long weekends and holidays. 
Her parents, Violet and Lou Mudrich, were still married, and still lived together, but somehow the house belonged to Ginnie's mother alone. Her father had his garage, his cars, his yard; the house itself was Ginnie's mother's domain. Lou seemed to prefer to stay out of Violet's way and out of her plans as much as possible. On one of Ginnie's last visits home, Violet told her about a new procedure she saw on television where a doctor injected a woman's forehead with some form of botulism or salmonella in order to combat her prematurely wrinkled brow.

"I wonder how much a procedure like that would cost, Ginnie. You know, you're too young to have so many lines on your face." Ginnie decided not to inform her mother that she was currently saving her spare change in a cereal bowl on her dresser, hoping that the accumulated money would fund the purchase of Estee' Lauder's new sweat-proof liquid foundation by the end of the month. Ginnie didn't want to depress Violet by bringing up money or anger her by suggesting that she was the main cause of the wrinkles, so Ginnie just quietly said she'd maybe look into it.

Ginnie couldn't tell Violet much about any part of her life without having to explain everything to her, and Ginnie had worked too hard for years to keep Violet from running loose through her personal life. Ginnie's infrequent trips to Coos Bay helped to keep Violet a little distant; Violet didn't become visibly angry at Ginnie's lack of visits, but she was disappointed enough that she kept her famous interrogation sessions to a minimum. Still, Ginnie dreaded going home. The trip was over three hours by bus, and Ginnie took along a small set of headphones and a Paul Simon tape; she always tried to nap on the bus, but it never worked. She floated in a semiconscious state, almost sleeping but still painfully aware of the other passengers, mainly those who refused to be ignored: screeching children with boxed juices and cans of soda, sucking loudly on their drinking straws, and sweating, foul-smelling old men in crackling acetate dress shirts. 
She thought of Paul Simon, the man rather than the recording artist, during her bus trips, looking at his picture on the cover of her cassette. He seemed like such a genuinely nice person, but Ginnie knew that everyone, Paul Simon included, had their dark side. Truth was, he might be a son of a bitch and no one in Ginnie's position would ever really know. She had read somewhere that he had basically ignored Carrie Fisher into divorcing him. If that was a viable option for all couples, Ginnie thought, her parents could have divorced long ago. Ginnie's father's only defense against Violet's attitude was to ignore her, especially in the years following Ginnie's moving out of the house. The strange thing was, Violet didn't seem to mind being ignored. Ginnie figured that it gave her mother more time to meddle in the personal affairs of her children. Either that, or her dad was secretly a bastard, which was something Ginnie wasn't prepared to believe could be true. She wished he still gave her twenty bucks each time she came home, but that didn't make him a bastard. 


\section{The Night You Shouldn't Have Taken Her Home}

She could crack ice cubes

in her mouth; she was showing

the bartender the technique

between sips of a fresh cosmopolitan.

She had been eating lime wedges

and he was steadily feeding her more.

Instead of taking heed,

letting that be a warning to you, you pulled up the next stool.

She turned, and her eyes were doe-like, all right, but you were incapable of realizing it was just a lot of kohl liner paired with coordinating eye shadows, complemented by the low light.

Her entire face was smoke and mirrors, next to nothing left in her cap sleeve, the rims of her eyes, her lashes, and the arch of her brows darkened just so, a deep russet brown, accenting her glossy, chemically-enhanced hair.

As you made yourself comfortable at the bar, removing your jacket, only looking away long enough to order a drink (and one for her), she had you, no struggle at all. 


\section{Omelet Boy}

"Hey, Omelet Boy!" someone shouted from down the street, somewhere behind Lee, followed by a faint, drawn-out "Egg Maaan!" Lee thought it sounded like Perry from work and stopped; then, realizing that his pause could be taken for a sort of nickname acceptance, he started walking again. Even his closest friends called him that; "No offense intended," they'd say, but Lee still bristled. Not that he was a stranger to nicknames; his mother had named him Cawley after a long-dead great uncle. Before shortening it to Lee in middle school, he'd endured names like CawCaw, Crawly, Crow, and anything else that eleven year-old boys could think up to elicit laughter from their giddy, tightly ponytailed classmates.

Lee's mother had saddled him with a bitch of a moniker, but she never saw it that way. Her eyes had welled up the first time he'd said to her, "Just call me Lee, Mom; at least in front of my friends." He had broken her heart, he was sure of it, and only now did he feel as if he should have stuck with Cawley. He'd take Crawly or Caw-Caw back in an instant if he could rid himself of Omelet Boy.

Ginnie had started the whole thing two summers ago, right after she dumped him. Anna and Mickey, mutual friends of Lee and Ginnie, had arranged a first date between the two of them. Lee had thought the relationship had promise at the beginning. As early as their third date, Lee was enough in love with Ginnie's ass alone to never want to leave her. What he didn't realize then was that the more he needed to be with Ginnie, the less she wanted him around. He thought he'd played it 
cool with her at first. He only spent the night at her apartment when she asked (which wasn't that often); then, he quickly lost sight of reason and began staying over as often as he could, invited or not, assuming his presence would keep her from dating other men. He thought that eventually she'd fall in love with him. His attempt to win Ginnie's affection by imposing on her eventually backfired.

Lee realized in hindsight that he had forced Ginnie to look for a quick end to the situation, but she had never bothered to talk to him about what went wrong or what she wanted to change. She'd never wanted to work things out, so she ended things one weekend with a massive, lingering dose of humiliation.

"I made him this western omelet one morning after the last of a whole week of nights he spent at my apartment," she told a group of their mutual friends, including Perry, who was the person who retold the story to Lee.

"I only did it because he was going to donate plasma on his way home. On an empty stomach, at nine in the morning! I was just trying to save him the embarrassment of passing out somewhere on the street."

Ginnie then told Perry and the others that after that breakfast, Cawley tried to sleep at her place all the time just so he could eat for free. "He was stalking me for meals," she said. "He was always showing up at dinnertime and shit."

He pictured her telling the same story over and over, perched on the edge of a red vinyl booth crammed with friends down at Doc's Pad, a Newport Light 100 in one hand, the other clutching a Cosmopolitan in a plastic cup. With a bottle of vodka and her big mouth Ginnie had christened him all right, but as humiliated as he was, she also made him believe that he deserved it. 


\section{She Met a Woman Who Was a Doppelganger from Afar}

While biking across downtown Eugene, she stopped to get something cold to drink at a little coffee house called The Higher Ground. She occasionally read manuscripts or novels there in the evenings, but she never frequented it in the afternoons; the daytime crowd being younger and louder than what she preferred. However, it was hot enough to change Ginnie's mind about riding straight home without stopping, so she tethered her bike to a nearby stop sign and walked up to the café. Balancing the weight of her backpack by cradling both her helmet and the bike's nylon panniers in her arms, she wrestled the door open with an elbow. There, clearing mugs and dessert plates from a table, was Ruth. Ruth sensed Ginnie as she would have sensed any customer in the doorway, and slowly made her way toward the small counter without looking up. Ginnie dumped her belongings into a ducttaped bistro chair at a vacant table and fished five bucks and change out of her bra. Her money was sweaty from the ride.

Ginnie squinted as she approached the bar to order, trying to focus on the barista without putting on her glasses---the woman wasn't Ruth, after all. Ginnie was slightly disappointed; her mind had already started weaving the story of how Ruth, unable to live without Ginnie any longer, had left her husband and traveled up from San Francisco to Eugene, moving here without Ginnie's knowledge. San Francisco wasn't really that far away, after all. For a moment she let herself think that Ruth was pursuing her, maybe even stalking her. However, the woman was wearing 
railroad-striped overalls, and Ruth despised overalls. Ruth had always picked on Ginnie for wearing them; they had served as Ginnie's outfit of choice for lounging around the house or going to the Laundromat. The barista, busy wiping the water spots off a few café ole mugs with the hem of her fleecy cardigan, was someone new.

The woman was tanned and a little plump and had olive-green eyes. She could have been Ruth's double, but Ruth's eyes were deep blue, almost indigo. The woman took Ginnie's order: a double iced mocha with skim milk and caramel syrup. Ginnie couldn't help staring at her, so she tried to do so with her mouth closed as the barista deftly prepared the three-dollar dose of caffeine. The woman smelled faintly of both Nag Champa incense and the scent of freshly-cut grass; to Ginnie, she smelled like summer. Ruth always wore expensive, classic perfumes; Ginnie remembered her wearing White Shoulders the day she packed her things and left. When the woman handed Ginnie her drink, then her change, the woman smiled. That wasn't like Ruth at all. A slight gap appeared between the woman's two front teeth. Ginnie tipped her two dollars.

Once Ginnie wound her way away from the bar and took the seat facing her chairload of junk, she was unable to ignore the woman. Ginnie watched her wipe the counter with a soiled dishtowel; the work she'd carted home from the office remained in her bag, neglected.

The woman's hips were fuller than Ruth's, but they were more graceful. Museum quality. Even a man would call them "rounded" instead of "big" or "chunky." The barista moved effortlessly behind the counter, washing a few more mugs and placing them to dry on a bamboo rack that hung on the wall behind her. Her overalls hung slack over her body. She looked soft; she was beautiful.

Even under the fluorescent light of the cafe, the woman's skin glowed a golden brown like Ruth's did every summer. It was almost seven years since Ginnie had seen Ruth naked for the first time; Ginnie had watched as Ruth peeled down 
to her black slip (the lace cups were sewn in by hand, she'd pointed out) their first night living together. Ruth had explained that the all-over tan came from wading in a lake near her parents' house all summer rather than going to a public pool or a tanning bed. Ginnie had tagged along the following weekend, and they spent Saturday laughing and picking snails off the rocks at their feet.

The woman was back to polishing the tabletops with a rag, sweeping bagel crumbs to the floor. It was obvious that the floors were not her job to sweep. The woman suddenly approached Ginnie and asked, "Is everything all right? Is the coffee okay?"

Ginnie realized that the coffee sat untouched in front of her. She smiled and said, "It's fine, really. It's great." She took a sip to assure the woman, only to realize that it was hot---the woman hadn't heard Ginnie say "iced" when she ordered. Still, Ginnie waved the woman back to her work and silently drank the steaming coffee. Ruth used to say that she didn't believe in iced coffee, so Ginnie tried to pretend that Ruth had made it, but it was delicious and Ruth's had always tasted burned. Ginnie smiled at the woman again from behind her mug. After finishing the coffee, Ginnie gathered her things. While Ginnie pulled on her backpack, the woman introduced herself, tried to start a conversation.

"I always see you ride past here in the afternoons, but you never stop. I'm Madeline. I hope the coffee was enough to make you come back," she then lowered her voice, "because the other customers this time of day leave a lot to be desired." She smiled at Ginnie, then made a face.

"I know; I usually come in the evenings," replied Ginnie, "for precisely that reason. It's quieter, and it seems to smell better, though that may be my imagination."

"Trust me. It's not," Madeline answered, rolling her eyes in mock exasperation, then laughing. "Maybe I'll see you around again." 
"Maybe," Ginnie answered, smiling back, knowing that she'd see her again as soon as possible. 


\section{A Childhood Fear}

As a child, she worried (as children sometimes do) about monsters under the bed, waiting to attack should the hem of her nightgown come into range of the narrow opening between the dust ruffle and the floor. She kept herself tucked into her bed tightly, sleeping in the dead center of the mattress, making sure not to curl up too closely to one side or another. She was afraid of making it easier to let a foot or hand slip over the edge of the bed, into harm's way, while sleeping. She wasn't concerned with being bitten, so much as what could follow a bite. She watched television as a child and learned that whole fingers and toes could be reattached, gashes and wounds sewn closed with catgut. She worried about the molars of a monster, and its jaws. If one decided to take her hand in its mouth and chew, grinding both the flesh and bones of her fingers to a mass of bloody gristle, a doctor could not fix it. Her father wouldn't be much help, either. When she asked him if monsters had molars, he pressed his lips together in a thin smile and hugged her. He never directly answered her. She was left to outgrow the fear on her own. She believes now that this contributed largely to the problems she has with day-to-day living. 


\section{Love Is Not a Fritatta}

Ginnie, her hair frizzed into an auburn inferno, wiped sweat from her forehead with the back of her hand; her bangs, sticky from melting hair gel, smudged her once carefully-penciled eyebrows into exaggerated, asymmetrical arcs that mocked the severity of her mood. She noisily shackled her bike to the porch banister and dragged her animosity for working-class America up her front steps like an oversized, sickly pink Mary Kay sample case.

Chuck impatiently wailed on the other side of the door as Ginnie fished through her pockets for the key. The Siamese didn't necessarily recognize the distinct clop of Ginnie's brogans on the porch, he just cried a lot, at everything. On weekends, Ginnie occasionally witnessed his caterwauling at the mailman or one of the house's other tenants. She waited for the day that someone would call the local Humane Society, thinking that the crying stemmed from abuse. Ginnie cringed at the idea of being turned in for animal cruelty; she wondered if she looked like a cat beater. All Siamese cats cry, she thought, but maybe her neighbors didn't know that. Ginnie nudged Chuck out of the open doorway and kicked off her heavy shoes. There were messages on her machine. She sighed and padded over to her desk. According to the Caller ID box, the messages were from her mother, one from Madeline, then two calls in a row from Anna. She clicked off the machine without listening to them. She wasn't in the mood for her mother or Anna, and she wasn't sure if she wanted to know why Madeline would call. Ginnie couldn't believe 
Madeline had called so soon; they had met two days before. Ginnie knew she had to tell Anna about meeting Madeline, she had to at least mention it casually, but returning Anna's calls never required listening to her messages.

Chuck, still cranky from spending the day alone, almost succeeded in tripping Ginnie by sliding between her ankles, feigning love. Ginnie knew he didn't love her; he loved the turkey-leg-shaped cat treats she kept out of reach in a kitchen cupboard. He followed her back to the front door; she reached a pale, freckled arm outside to grab the mail that she'd ignored on the way in.

"Wait a goddamned minute," Ginnie said to the cat; he meowed loudly whenever she talked directly to him. She thought about the mailman as she closed the door behind her. Young, and handsome for a mail carrier. Ginnie thought he looked like French Stewart: squinting eyes, squared-off hair, chinny from a slight underbite. He had odd facial hair, though, sideburns that almost touched in a sort of Amish beard. She tried to wait for the mail on Saturday mornings, hoping that Chuck would announce the mailman's arrival, but the cat sometimes slept through the delivery: maybe he did it out of spite? She thought she could go to the door to retrieve the mail directly from him, maybe engaging him in conversation, but she often missed his visit. Ginnie once heard a neighbor call him Bruce. Ginnie didn't think he really looked like a Bruce, but she was not sure what she thought his name should be.

Ginnie's mail was mostly magazines on Fridays; she subscribed to almost a dozen. She liked to have them to take to the office; she had trouble concentrating on bad fiction, especially while seated at one desk in a room of desks, fluorescent light looming over her like an ever-present deadline. She read magazines, made grocery lists, balanced her bank accounts for the largest part of her work day, then caught up on reading manuscripts at home, in private, in the evening. 
Ginnie put some water on to boil, then dropped some Pounce on the floor for Chuck, whose patience had worn thin. Circling the small apartment, lowering the blinds and turning on a few lamps, Ginnie paused in the bedroom long enough to fetch a pair of flannel pajamas. She finished pulling on the bottoms as she added pasta to the water on the stove. Not in the mood to doctor up store-bought marinara, Ginnie pulled the end of a stick of butter and a small jar of minced garlic from the fridge and set them on the counter to toss with the pasta when it was done. Chuck, still licking the taste of salt and fish from his chops, watched Ginnie from the kitchen table.

"You are a cat, and you do not eat pasta," Ginnie reminded him, shooing him down. "Why did I ever let you develop a taste for people food?" She adjusted the waistband of her pajamas with one hand while searching through the cabinets for the colander. The phone rang, startling her and the cat, who dove under the nearest overstuffed chair. Ginnie was hungry, and she hoped that it wasn't Anna on the phone, interrupting dinner.

"Hello?" Ginnie answered, turning off the heat under the boiling pot.

"Ginnie? Hi. It's Madeline. From the other day?" Ginnie froze. She wasn't ready to talk to Madeline; she hadn't rehearsed anything to say. "Did you get my message? I called earlier, but you weren't home. I know you bike to and from work every day, but I don't really know how far you live from downtown. I remembered that after I'd already left the message. Sorry if my call seemed too eager, but I really thought you'd be home already."

Ginnie thought Madeline sounded nervous, but she couldn't be sure; they'd just met. However, the fragmented apologies put Ginnie at ease, and she drained her pasta while Madeline spoke.

"I was surprised, more than anything. I didn't expect your call , but I'm really glad you did. Call, I mean," Ginnie said when Madeline paused to take a breath. "I 
figured you could've thought I was some sort of lunatic. I mean, I know you introduced yourself, but then I just forced my number on you. I don't usually try to make friends so aggressively. Frankly, I felt like an idiot after I did it; I didn't think you'd call at all."

"Oh, don't feel like that," Madeline sounded like she was relaxing a little. "Like I said before, I've seen you ride your bike past the front windows of the Higher Ground, and I asked the night barista about you after you mentioned that you usually came in during the evenings. She vouched for you, said you seemed really nice. So it's not like you're a stranger."

This made Ginnie smile; she had mistakenly thought that Madeline was new at the café. Apparently Madeline had noticed Ginnie first, and she was honest enough to admit it. Ginnie set her dinner aside to give the conversation her full attention, curling up on one end of the sofa to make room for Chuck, who had crawled out from under the chair and was looking anxious to join her.

米

"Have you been seeing anyone new lately?" Anna asked, rather suddenly, just before their salads arrived.

Ginnie narrowed her eyes; she was still panting, recuperating from her ride to the restaurant; she had dodged coddled Lincolns and Cadillacs as, for the first time in history, all the churches in downtown Eugene let out simultaneously. She was a few minutes late, and Anna had waited patiently while Ginnie arranged her helmet and panniers in a vacant chair. Ginnie could sense that Anna was agitated by the clumsy entrance. Ginnie had accidentally let go of her handlebars, allowing the bike to fall into the plate glass window in the front of the café. The window hadn't broken, but the bike's weight had boomed off the glass, reverberating through the 
Solstice. Anna had, meanwhile, sat inside at their usual table, mortified. Their preordered slice of cheesecake was nestled in the center, between their place settings.

"Wait a minute, before you start in on me," Ginnie countered. "I don't want you to set me up any more, at least not for a very long time; I should have known that you were going to ambush me this afternoon; you didn't bring this up, not even once, on the phone yesterday. That should've clued me in." Ginnie deliberately did not answer Anna's question. She wanted to change the subject to less sensitive issues, but the question irritated her. When she opened her mouth again, she was antagonistic.

"I don't want to date anyone that you know----I know most everyone that you know, and they are collectively not my type," continued Ginnie. "And ultimately, it infuriates me that you keep trying to goad me into dating Cawley again."

"Lee? Well, you know I only set you up after Mickey had first told me that Lee read all the time and was really funny. Then, when I finally met him, I thought he was just great. I still stand by my assessment that he's really sweet and that he really cared about you a lot." Anna was beginning to grow defensive already; Ginnie knew that she should drop the subject, but she couldn't.

"What, just because he never incited a riot at the plasma center, I should've been grateful to have him?"

Anna's neck flushed with irritation. She grew noticeably embarrassed of it as the waitress approached to deliver their salads and take their sandwich orders. Anna tugged at the neck of her blouse.

This is great, Ginnie thought, our sandwiches are barely ordered at this point. She wasn't even sure whether to bring up Madeline at all now. Perhaps the lunch date had been a bad idea. She knew she had to say something to make Anna feel better, or she'd walk out on Ginnie. 
"Jesus Christ, calm down, Anna. We're supposed to just be talking here, making pleasant conversation ... and in case you've forgotten, you're the one that picked this topic, so don't start getting defensive and pissy with me!" Ginnie immediately realized that swearing at Anna and calling her "pissy" wouldn't remedy anything, but she casually chewed her way through a large mouthful of endive tossed with sunflower-kernel vinaigrette while looking at Anna with her eyebrows raised, as if it should have. Anna said nothing, so after Ginnie swallowed her salad, she continued.

"Now, honestly, for that whole Cawley fiasco alone I deserve a break from your matchmaking services. You met that homeless crud picking up Mickey from work, then didn't bother to tell me that he was a donor! I thought he worked there! I am not going out with any more plasma donors, so save your time. Think ahead, live your own life; sew some curtains for the nursery."

"How can you be so materialistic?" Anna asked. Now beyond taking offense; she looked crushed. "How can you treat me like I don't care?"

"About the curtains?" Ginnie asked, almost laughing.

"No! Quit playing around; now you're just trying to make me mad! Why would you rule someone out as a boyfriend just because he sells plasma every now and then for pocket money?" Anna looked chafed, Ginnie wondered if she was itchy. She added, quietly, regaining some composure, "He had a real job while you were together, and he's not homeless, either, Ginnie."

"Well, Anna, in my own opinion I'm too old to have boyfriends, first of all," Ginnie gave up on being polite and settled into Anna's anger like an old comfortable chair. She loved feeding it, and a long time had passed since Ginnie had last seen this side of Anna. It was good for Anna to occasionally get all of it out of her system.

"Furthermore, Anna, I know he had a real job----taking advantage of my generosity! He was constantly tricking me into inviting him to sleep at my house, 
and then he'd eat all of my food! So, you're telling me that on top of that, I should have been fucking him without complaint, too? No man deserves food, lodging, and a piece of ass. Not from me. If I was ever thinking of breaking that rule and giving all three away, Cawley would never ever be my first choice."

"He doesn't like to be called Cawley," Anna reprimanded quietly. "You know that." Ginnie had been waiting for it.

Anna appeared to be afraid to look around the café. Filled with older women in pastel suits, some with matching hats, lunching after church, those nearby had to be ferreting words and phrases like fuck and Jesus Christ and piece of ass out of the conversation. There were at least a few, Ginnie was sure, staring with blatant disapproval at the type of exchange the two friends were having on the Sabbath.

Ginnie loved it. She had an audience, and she wasn't holding back. "Besides, I don't know why you're so attached to the idea of Cawley and me together. I mean, Mickey picked him out solely because he saw him reading a book. I could probably agree with Mickey's caveman logic: Hey, they both like books. I betcha they'd fall in love. However, Lee was reading that book while a needle drained away twenty bucks worth of white blood cells! Where is the romance in that, exactly? What is it about him that I've overlooked?"

Anna waited to be sure that Ginnie's diatribe had come to an end, then she took a deep breath. She smiled. "Let's not get into this, Ginnie. I'm tired of arguing with you ... no, I'm tired of listening to you argue. If you don't want to go out with anyone I know, then that's fine. I can respect that. Go ahead and keep fantasizing about your mailman or that boy at the gas station; fulfill your dream of becoming your neighborhood's crazy old cat lady. I just get so mad when you don't let me explain things. I don't want to set you up on a date. I just think I need to shut up now and let today's lunch conversation be the lesson that teaches me to butt out of your love life." 
Ginnie started to realize that she had pushed Anna too far. "Listen, Anna, I'm not trying to hurt your feelings here. I know your intentions are good, but I'm really picky about who I spend my time with. Besides, I'm not even in the market right now for a man to waste my time on. Let's just drop it, like you said, and forget it ever came up. Just let me ask, though, who is this person that you wanted me to meet for a non-date?" Ginnie waited, wondering if Anna finally saw Ginnie's side of things, but knowing too well that Anna wouldn't be able to drop the subject until Ginnie knew everything.

Anna's face curled into an exaggerated, child-like pout. "I didn't mean that I was looking for someone new for you. It's just that . . well, never mind. You're going to get angry, and this is supposed to be special----a nice lunch between good friends."

"No. Don't pull that, Anna," countered Ginnie. "You're going to tell me exactly what you had mapped out for my personal life. Don't you ever consider the possibility that I could find someone on my own, and now you're dangling that mistake in front of me?" Again, Ginnie waited. Ginnie thought to herself, what is so special about meeting her for a lunch of wilted salad greens and white-bread sandwiches? Still, Anna sat silently.

"You know, Anna, I met someone this week and I don't even know how to tell you about it because you are driving me out of my mind by talking about someone that you think is perfect for me! So, let me reconfirm that nothing you could say could make things worse than they already are. Out with it!" On top of everything else, Ginnie was pissed at herself for losing control, for letting Anna get to her.

"You just seem to take a great pride in making yourself and everyone around you unhappy," started Anna. "I worry about you; you're trying to make yourself 
the least tolerable woman on the planet." She paused, looking surprised at what she'd just said.

"Please, Anna, don't stop there. Don't hold back now; finish!"

Anna looked around at the other people eating lunch. She looked anxious to leave, but she softly finished what she wanted to say. "Lee wants to see you. He wants to apologize. He was thinking that if you weren't seeing anyone else you might consider giving him another chance. He's been eating dinner once or twice a week at our place, and he's totally heartbroken. Even though you treated him so badly, he still really misses you. He says everything was his fault. He says he saw you last week. He says he loves you." Anna's voice trailed off to a wisp of sound by the end of the speech, as if she was breathless. Ginnie wondered, was Anna hyperventilating or merely over-dramatizing?

Ginnie hated what she said next, knowing it would probably hurt Anna as much as Lee. "I don't have the strength to make that boy any more breakfasts, Anna; I can't. He has confused eggs and cheese with true love. Let him find a new girlfriend with an omelet pan and a need to feel domestic."

"Ginnie, I'm through with this. I just want you to be as happy as I am, and I think being with Lee could do that for you."

“Then you've never really known me at all; all these years, you've been acting!" Ginnie snapped, but she regretted saying it as soon as she saw Anna's face. Anna, eyes welling up, immediately found her purse, pulled it open to retrieve her wallet. Laying a twenty and a ten on the table, she stood up without a word.

As Anna pushed her chair in, she looked at Ginnie one last time and said, "Tell the waitress to wrap up my club sandwich, so you can take it to the office for lunch tomorrow." With that, she turned and walked out, leaving Ginnie alone. 
Ginnie pulled a fresh pair of pajamas from her bureau, even though it was only five in the afternoon. She had sat in the restaurant for a good hour after Anna walked out, trying to figure out how she could make everything right, wondering if the friendship was even worth fixing. After searching the drawers, Ginnie opted for a newer pair her sister had recently brought back from a business trip to Japan; white cotton, sprinkled with smiling garden vegetables and the words "Happy Tomato." She removed her bra before pulling on the top, releasing herself, not planning on seeing anyone for the rest of the night.

Ginnie filled a kettle and put it on to make tea, but as she searched the cupboards for something herbal, preferably with berries, all she could find was a box of an organic PMS blend that Anna had once bought her. Ginnie put it back and turned off the burner under the kettle, opting instead for a can of Coke.

She scratched the bridge of her nose with the cold rim of the can as she headed for the sofa and a pile of manuscripts, determined to catch up, at least a little bit. 


\section{The Foolish Confidence of Girls Who Do Not Wear Bras}

Her breasts outgrew the handful stage over ten years ago.

She remembers wearing flowered undershirts at thirteen--stretch marks from rapid weight gain not yet visible.

She had no fear of gravity; her tiny nipples still tilted upward, buoyed on the most delicate scoops of flesh.

And these girls would saunter into the store where she was once employed as the counter help; their young breasts bounced slightly with each step, still years away from becoming mammaries, flawless in their pale frailty, like Hostess Sno-Balls, they too tasted, perhaps, like coconut or chocolate, as they floated under summer-weight halter dresses.

They seemed suspended just inches below twig-like collarbones-They walked through the door, jostling those breasts into a trendy mix of other accessories: butterfly-shaped barrettes and faux tortoise-shell sunglasses tangled in their long hair, browned and waxed and StairMaster-ed legs.

She hated those girls, breasts most of all, and she silently waits on them to catch up. 


\section{In a Manner of Speaking}

I always wanted to be her friend, even before I actually met her. I was dissatisfied with my friends, knowing something better was available, but not knowing where to locate it. When I was finally introduced to her, I felt at peace, at least with that portion of my life. She fit into my everyday existence perfectly, seeping into the cracks and empty spaces, filling my free time. I did not mind; I was glad to have her there.

She was angry most of the time, at nothing more often than something, and it took me a little time to grow accustomed to dealing with her unfocused rage. She sometimes talked about seeing a doctor, trying to find a pill or a therapy that would help her. Most of the time, however, she didn't feel as if the absence of her anger would be an improvement, she was afraid that by trying to change herself she would stop being herself. She didn't actually talk to me about this, but her thoughts were often spoken out loud. The thoughts often opposed each other, sometimes only sentences apart.

She told me on the night that I met her that she had once slept with a lunatic, back when she was collecting men. She explained that she did it to put an element of competition into her life at a time in which she was incredibly bored; she had decided to start sleeping with oddballs, creating a gallery of experiences with which no other woman could really compete. She soon grew tired of collecting men, because her friends thought it was wrong. She said she often did not listen to 
her friends, but she agreed with them that one time, but only because she herself thought that the hobby might have been in poor taste.

After saying that, she then launched into a list of men she had slept with, despite the fact that she disapproved of the activity. She told me she had slept with a man who said he was a juggler, though he was really a vagrant with no balls or bowling pins with which to juggle. She'd slept with a man studying to become a minister. She'd also slept with a man whose job was to walk around in a furry Fred Flintstone outfit in an amusement park somewhere in the middle of Ohio and a man who sold Schwan's ice cream and frozen foods like pre-fried chicken fingers out of a refrigerated truck. She talked most about the lunatic, though. He was really just a young man from her hometown who had paranoid schizophrenia, but she always referred to him as a lunatic. I never asked her if she called him that to his face, but on certain days, she might have.

The lunatic, as well as his older brother, were both friends with her little brother; that was how she met him. She said that when she'd first seen him, not knowing much about him because her brother was not inclined to describe his friends in great detail, she'd thought he was just another one of the eccentrics that comprised her brother's limited universe. He'd had on an old man's trench coat that looked black from a few feet away but was actually a dark green and black plaid that smelled slightly musty, as if it had been stored in a basement. He carried a cane, though he was not lame and did not use it, and he spoke in an English accent. She'd been drawn to him; he seemed somehow too peculiar, or perhaps a text book example of what a peculiar man could look like. At the same time, he didn't seem as if he were actively cultivating that look. She'd noticed his accent when he introduced himself, but when she asked him where he was from, he said "Virginia." She laughed, and he then took her hand and kissed it. 
She told me that she thought she could've loved the lunatic, she knew it at that moment, but she always tried to improve the men she dated. She was afraid that she'd always think that she could make him just a little more sane, that she would grow frustrated when she could not. She knew that he occasionally heard voices; she'd often tempted to ask him what they said, but she didn't.

He couldn't drive, and he received a check from the government every month that he said was to keep him from trying to get a job. She saw him occasionally, walking to a gas station to buy cigarettes, and she would pick him up and drive him there and then back home. One afternoon, she was wearing striped tights with buckled shoes when she stopped to give him a ride. As he climbed into her car and noticed that she was wearing those tights, he said she looked like a hornet. He asked her to go to bed with him, and she agreed. They went to his house, and with his brother in the very next room watching television with friends, they had sex in his bed. Afterwards, she slid out of the house, past the brother's room, and drove home.

After that, she had trouble rationalizing her feelings for him. I understood when she got to this part of telling the story that this was the reason, not her friends' disapproval, for her giving up collecting men. I was disappointed in a way to see that she could be vulnerable, but as she and I became friends, I began to know her better. I realized that one of the only times she looked as if she had a heart at all was when she talked about the lunatic. However, her seeing him went no further, because her brother found out from his brother what had occurred. Her brother threatened to break the bones of the lunatic and then to tell their parents what she had done if she ever saw him again. She decided to stop seeing him, even stop giving him rides, since that was how everything had started, because her parents knew the lunatic well and knew of his condition. She was also afraid of what would happen if she was to begin a relationship with him, but for different reasons. I believe that she wasn't 
angry around him, and it worried her, because she could not change him but he might change her.

In a manner of speaking, she told me, if he had never told me I looked like a hornet, I probably never would have fucked him anyway. She seemed sad when she said it. I could tell that she was lying, because she is used to telling the truth and doesn't lie well. But then she changed the subject, moving on to talking about the juggler or Fred Flintstone, and she was mean-spirited again. 


\section{She Frequented a Gas Station}

She frequented a gas station that was near her home, though she did not have a car and could not, therefore, buy any gasoline. A younger boy worked at the gas station, and she found him attractive. He did not work any set shift; often when she approached the gas station after walking there and contemplating what to buy inside, she would enter to find that he was not working. Guilty, she'd buy something anyway, not really needing anything.

The boy had long, dark roots on his short, pale blond hair and black tattoos all over his arms. Tongues of black licked out from under his shirt sleeves and made her curious about the artistic license he took with the rest of his body. Then she felt embarrassed, dirty, knowing the boy was probably fresh out of high school, and she, though barely thirty, was probably closer to his mother's age than his. Those feelings, however, did not make her stop frequenting the gas station.

She bought gum in plen-T-packs, foam cups of hot coffee, cigarette lighters, ice cream sandwiches, magazines, and key chains, and she ran out of things to buy. She wished the store sold wine. She began to smoke, to have something to buy and to use up some of the lighters she had already bought.

She dressed in a certain fashion to go to the gas station, and although it made her feel bad about herself, she could not stop herself from doing it. She thought of herself as a tarty older woman, wearing pedal pushers and high heels and fluffy hair and over-applied cosmetics, with earlobes pulled long by dangling earrings 
resembling hand-blown glass Christmas ornaments. Was that how the gas station boy would see her, did see her? She was afraid of looking like a drag queen, or a female impersonator of a drag queen, so she always made a conscious effort to play down her jewelry and makeup. However, she could not stop herself from buying tight blouses in velvet or subtle animal prints to wear to the station; she could not turn away when faced with them in a department store.

At the gas station, she believed the boy showed an interest in her. He would hand her change to her, and say "have a nice day" while looking her in the eyes. He smiled at her, and he had a nice smile, but one front tooth, a top fang, was slightly discolored with what was probably a slow rot. She was sure, at times, that he found her attractive. At other times, she wondered why she associated his brief eye contact with being found attractive.

His name was not embroidered on his shirt pocket. There were no visible tattoos with his name in them, either, though she thought of that as a positive thing. Still, she was frustrated; she thought all gas station boys should wear shirts with their name embroidered on the pocket, names like Vinnie or Larry or Sal.

She knew she could grow old simply admiring the boy, that she had no desire to engage him in conversation, afraid of finding out how stupid he really was. In contrast, if she let herself believe that he was smart, then he would eventually leave the gas station, for a better job or for college. She preferred to think that he was just a little dim, in an endearing way. If he stayed silent, he would not interfere with her opinions of how he should behave. Sometimes, while buying a pack of cigarettes, she looked at him as he squinted, pecking at the keys on the cash register. His nails, though dirty, looked buffed. She stood there wishing everyone fit into her life as well as the gas station boy, wishing everyone tried to avoid disrupting her opinions of how they should behave. Then she noticed how the blond hairs on his forearms stood out over the black ink of his tattoos, and she lost her train of thought. 


\section{Dinner for Two: Discussing a Third Party, Alluding to a Fourth}

She finished dressing for dinner by fidgeting with various accessories in front of a mirror. She finally chose to wear a silver charm bracelet and a pair of small garnet earrings, but only after scattering the entire contents of her jewelry box across the top of the bureau. She had planned to wear a brooch, but the fabric of her linen sundress was not strong enough to support the weight of one. After fastening the bracelet, she left the bedroom quickly before changing her clothes again.

As she slid on a pair of cork sandals, the doorbell rang. She finished buckling the shoes' straps before answering the door, collecting herself, not wanting to appear too eager. When Madeline had called two nights before to ask her to dinner, she had eagerly said yes. She didn't want eagerness to seem like a dominant personality trait.

Madeline stood on Ginnie's porch in a pair of fraying Levi's and a pale green twinset, the color of a honeydew melon. She had her hair tied back with a leopardprint scarf that coordinated with her hair color, but matched nothing she was wearing. She was barefoot. Ginnie stared at her feet.

"My shoes are in the car," Madeline announced, as Ginnie looked up from Madeline's maroon toenails. "I don't like to drive wearing shoes."

Ginnie looked over Madeline's shoulder to the car. "Isn't that illegal in this state?" she asked, distracted by the vehicle's appearance. It was an ancient Volvo 
station wagon, cornflower blue, though the paint was flat and had been applied with a brush directly over everything, the chrome emblems, the scabs of rust along the bottom edges of the doors, the door handles.

"Well, I don't know. It's how I learned," said Madeline, not crossly. Again she followed Ginnie's stare, this time to the car; she blushed, and then she explained. “The car is my landlady's. I don't own one, and I was running a little behind, so I asked to borrow it. I was going to ask you if I could just park it there, anyway. I thought we might walk to the restaurant; it's only ten blocks or so from here."

Ginnie, tearing her gaze away from the car, self-conscious suddenly of her own staring, joked, "Well, are you going to put some shoes on? Or do you have to walk barefoot as well?"

"You ass, of course I am," Madeline made a face and walked to the car, fetching the keys from the ignition, then searching the back seat for shoes. She finally located a pair of battered ballet flats and tossed them down onto the sidewalk, scuffing into them. She smiled at Ginnie.

"I think it'd be nice to walk; the sun's going down," Ginnie answered, a little late for her opinion to matter. Madeline had already pushed the car keys down into her front pocket.

As they began to walk, Madeline turned to Ginnie and said, "I love your sundress. It's the color of a good milk chocolate."

Ginnie laughed. "That's the first thing I thought when I tried it on, when I looked in the mirror. I had to buy it." Ginnie paused, then asked, "Your landlady's car?"

Madeline laughed. "I rent a garage apartment. A carriage house, really. My landlady lives in the main house. She lets me use the car when I need to. The trade off is that I bring her mail in to her every day so she doesn't have to walk to the end of the driveway. We have a drive-by mailman; you know, a box down on the curb." 
米

"I really need to tell you something," Madeline began, speaking slowly and leaning into the table toward Ginnie. Her hesitation and apparent secrecy suddenly made the dinner slightly awkward for Ginnie. "I feel like I've been keeping this big, dirty secret from you. I'd feel a lot better if I just came out and told you now, before we start spending a lot of time together, before I start wanting to keep it from you. You wouldn't trust me anymore. So, I think I'd rather say this before you start trusting me at all."

Ginnie had never heard Madeline say so much at one time. She put down her fork and tried to furiously work her last bite of lamb curry into something swallowable. After a few seconds, unable to choke down the mouthful, Ginnie answered quietly through the pulpy meat, her napkin held up to her lips.

"You aren't making any sense, Madeline; just go ahead. How bad could it be? We only met a few weeks ago, so I don't think you could actually say you've had much of a chance to keep anything from me yet. So what is it?"

Madeline looked away from the table. Ginnie's stomach lurched; she feared that the evening was turning into a melodrama.

"I'm married." Madeline blurted; she looked embarrassed.

"I'm sorry; what?" Ginnie asked, a little loudly, not sure of the exact meaning of the revelation. "I mean, well, what do you mean, married?" Ginnie wanted clarification, an excuse, anything.

"Well, it's not as bad as it sounds, but I'm not going to try to make excuses for my past. I can't do that."

"Well, I don't think you have to. I don't think that your being married is something that anyone has to excuse, especially me. Maybe I don't understand why 
you're telling me this," Ginnie said. She only wanted to try to become friends with Madeline, but she still felt somehow jealous. Jealous, knowing that Madeline, like all the other women she knew, would have less free time to spend with a single friend because of a full-time man, but Ginnie felt like there might be more to it than that. She just hadn't had a chance to work it out yet. She just knew she didn't want Madeline to be married.

Madeline pressed her lips together before she started talking again, as if the action could help her determine where to start. The everyday clatter of the restaurant was amplified in the brief, weighted silence at their table. Ginnie began to wonder, was Madeline attempting to drop the subject? Then, Madeline took a large drink of her wine and began to speak quietly, secretive again.

"I've been married since I was twenty, almost eleven years, but my husband lives near Pittsburgh with his girlfriend Thea and their two-year old daughter, Katey. Douglas and I only lived together for about a year; we spent a few months together here, a summer together there, that sort of thing. It was never very traditional, but I've been trying to talk him into divorcing me and he won't. And that is the truth." Madeline looked far from finished, so Ginnie remained silent, interested. Among other things, she hadn't known that Madeline was older than her. She'd not thought to ask.

"Douglas and I went to high school together, but he was older than me; we didn't start going out until the end of his senior year. We dated off and on for a few years, and when he graduated from college in Ohio, he moved to Pittsburgh to be near me while I finished school. We got married that first summer. We only lived together for about four months before he decided he'd like to rent a little studio apartment closer to work. The traffic there was awful, and his ride across town 
sometimes took forty-five minutes, so I agreed. He was working as a computer instructor at one of those computer superstores, the kind that gives free lessons to businesses when they buy a whole new system. I only saw him on weekends."

"Didn't that seem strange to you?"

"Well, he was making decent money, and I had more time to study and go out with my friends without him always around, and I had my very own apartment because he could afford to pay for my rent without me having to find a roommate to split the expenses. Some of my friends were splitting rent with five or six other girls. I thought I had it made. Plus, I loved him dearly."

"What happened?" Madeline's story seemed so foreign to Ginnie; she wanted to know everything. The concept of being married but living apart in the same city seemed implausible to her; almost absurd.

"Well, I was twenty, first of all. I think that's what happened. I loved Douglas, but sometimes I felt like a big loser for being married. Then I met someone else."

"You! I thought you were going to tell me that he left you!" Ginnie exclaimed.

"Well, he did do the official leaving, shortly after I let a friend move in with me. Her name was Frances, and I knew her from school. She got kicked out of her apartment, so I talked to Douglas about letting her move in with me. I figured he and I could spend our weekends together at his place, and the extra money from her half of the rent could be my allowance, in a way. He agreed that I should do it. Well, before long, Frances and I realized that we had a lot more in common than we had thought. We spent a lot of time together, and things between us just naturally progressed." 
Ginnie thought about her own experiences in college, and they didn't seem to measure up. She suddenly felt shortchanged. At the same time, she didn't know what to say to Madeline. It showed on her face.

"Doug had told me it was all right to see other people, to have fun and enjoy college, but that he didn't want me living with any lovers while he was paying my rent. Understandable now, but at the time, I was furious. Douglas quit paying my rent; I started waitressing."

"Soon, Douglas took a transfer to Boston, and we stopped pretending we married. We worked things out, remained friends. He's back in Pittsburgh, and I stay with him and Thea once or twice a year when I'm in town. Thea's a great match for Douglas---headstrong but domestic---and Katey is just gorgeous. They actually asked me to be her godmother, but I thought it was in poor taste, considering that I am still Douglas' wife and Thea officially is the mistress. But, Douglas is happy; I know he wouldn't be happy if we were still together."

"Well, if you don't mind my asking, then, why are you still married to him?" Ginnie didn't want to pry, but felt at that point that she probably wasn't. Madeline didn't seem guarded about much of anything.

"Well, that's hard to explain. I don't really know. I know he loves Thea, but I think he's just happy where he is. I think he just doesn't want to rock the boat with me or Thea. She's never brought up marriage, and he's afraid to, though she's much more of a wife than I ever was."

"Well, I appreciate your being honest about being married, but first of all, it doesn't seem like you're really married, and second, I'm not sure if it's really any of my business, anyway," Ginnie said, still puzzled, hoping Madeline would explain why it was so important to tell Ginnie what she just said. 
"Well, if I would have waited and then told you that I was married, but that it wasn't a real marriage, you'd probably not believe me. Plus, I've made a lot of mistakes, and I just like people to know what they're getting with me."

Ginnie didn't want to read anything into her new friendship, so she still had no clue what she was getting. She wondered if that was the point, if that was Madeline's intention. Madeline excused herself to the restroom, leaving Ginnie to wonder, mainly about Frances and where she was now. She wanted to have done everything Madeline had done, and she felt cheated; even more, she felt for the first time as if she'd lived a sheltered existence.

Madeline returned, slightly startling Ginnie. "Let's go to the coffee house for dessert. I happen to know that Joel's wife baked a blueberry and vanilla wafer cheesecake last night for the café, and I think he's saving us two slices," she teased.

Ginnie looked up at her and smiled; Madeline sat down, and the two waited, anxious for their waitress to bring the check.

"I guess I should have realized years ago the perks of having a friend who works within the vortex of the cheesecake universe," Ginnie laughed, forgetting for the moment about Frances and about being sheltered, allowing herself that. 


\section{The Day I Met the Barista Who Took My Place}

As she took my order, I knew by her small pores that she was yours--skin scrubbed to bright pink on the cheekbones, a dust of freckles across the bridge of her slender nose, long, pale hair worked into a loose knot with a chewed-up pencil.

She leaned over the counter with my change caged in her fingers, her wrist exposed; she wore it under your favorite gray sweater. Even closer, under her apricot cologne, through coffee steam, through the scent of milk lather and honey, I could smell you. 